\title{
Rethinking Journalism Education in Spain: The Gap between University Studies and the Labour Market
}

\author{
Patricia González-Aldea \\ Universidad Carlos III de Madrid, Spain \\ Eva Herrero Curiel \\ Universidad Carlos III de Madrid, Spain \\ Carmen Marta Lazo \\ Universidad de Zaragoza, Spain
}

\begin{abstract}
The main purpose of this paper is to analyse whether professional skills demanded of journalism graduates by companies match university curricula. In the current digital context, adapting journalism studies to labour market changes must be considered. A review of the literature shows much research about this topic in recent years, but, given the rapid changes that occur within a field that is increasingly global and technologically oriented, regular research is necessary. Content analysis has been carried out by evaluating journalism employment offers found on InfoJobs and Linkedln--the two most used human resources web sites in Spain--and their correspondence to journalism curricula according to ANECA (the Spanish National Agency for Quality Assessment and Accreditation). From an initial sample of 310 job offers, 156 were ultimately selected, discarding those that were repeated or not expressly addressed to journalism graduates. All the information provided in the employment offers was organised into two categories based on the skills required and the descriptive data in the professional profiles demanded. The main findings show not only that it is becoming ever more common for enterprises to look for candidates with abilities which reflect experience closely related to Web 2.0, but also that these same companies apparently tend to ignore traditional journalism skills. It is also true that they do not seem to know precisely what skills a graduate in journalism should have. Knowledge of marketing is included in $47 \%$ of the positions offered to journalists, when this is not a subject included in journalism curricula.
\end{abstract}

Keywords: Rethinking Journalism Education in Spain: the Gap Between University Studies and the Labour Market

\section{Introduction}

\section{Journalism Studies in Spain}

Journalism in Spain began as a trade, with the Spanish daily El Debate and the Official School of Journalism opening academies for it in 1926 and 1939, respectively. Later, in 1971, it was offered as a university degree at the Universidad Complutense de Madrid and the Universitat Autònoma de Barcelona.

What began as a trade rooted in tools and technique (Graña, 1927; Beneyto, 1958; Benito, 1967) became more theoretical at universities in the 1970s. In the 1990s, new matters were addressed, such as the structuring of the general teaching of journalism (Real, 1997; Galdón, 1999) and the balance between social science and humanities subjects and subjects specialising in communication, with an appropriate proportion of theory and practice (Gordón, 1991; Humanes, 1997).

The adaptation of the degrees to the European Higher Education Area (EHEA), explained in the guidelines of the Libro Blanco. Títulos de Grado en Comunicación (ANECA, 2005), presented a change in the formulation of university studies for communication and journalism degrees in Spain. The model for learning went from being grounded in objectives to a model based on the acquisition of skills for professional application (Marta-Lazo, 2010; Sierra and Cabezuelo, 2010; Real, 2012; 
Marta-Lazo, Agustín Lacruz and Ubieto Artur, 2012; Marta-Lazo and Vadillo Bengoa, 2013; Rodrigo-Alsina and Lazcano, 2014; Sánchez-García, 2016).

The four professional positions the Libro Blanco (2005: 191-192) contains are:

-Copywriter of journalistic information for any type of medium

-Editor-in-chief for press or institutional communication

-Researcher, teacher and communication consultant

-Web site administrator and content editor

The Libro Blanco (ANECA, 2005, pp. 210-213) lists 15 professional skills (know-how) pertaining to the four positions. The skills were rated on a point scale ranging from 1 to 4 , and are ranked below according to the average scores they received.

\section{Graph 1. Professional Skills of Journalism Graduates. Libro Blanco}

Basic ability to communicate in other, neighbouring languages

Ability and skill to design formal and aesthetic details

Understanding of the data and mathematical operations performed and currently used in the media

Ability to conceive, plan and carry out news or communication projects

Ability to experiment and innovate through the knowledge and use of applied techniques and methods

Ability and skill to perform basic journalistic tasks

Ability and skill to use news and communication technologies and techniques

Ability and skill to use computer systems and resources

Ability and skill to present reasoned ideas

Ability and skill to communicate in the specific language of all traditional and new media

Basic ability to understand news production in standard English

Ability and skill to search for, select and prioritise any type of source or document

Ability and skill to collect, organise, analyse and process information and communication

Ability to read and analyse specialised texts and documents

Ability and skill to express oneself with fluency and communicative effectiveness

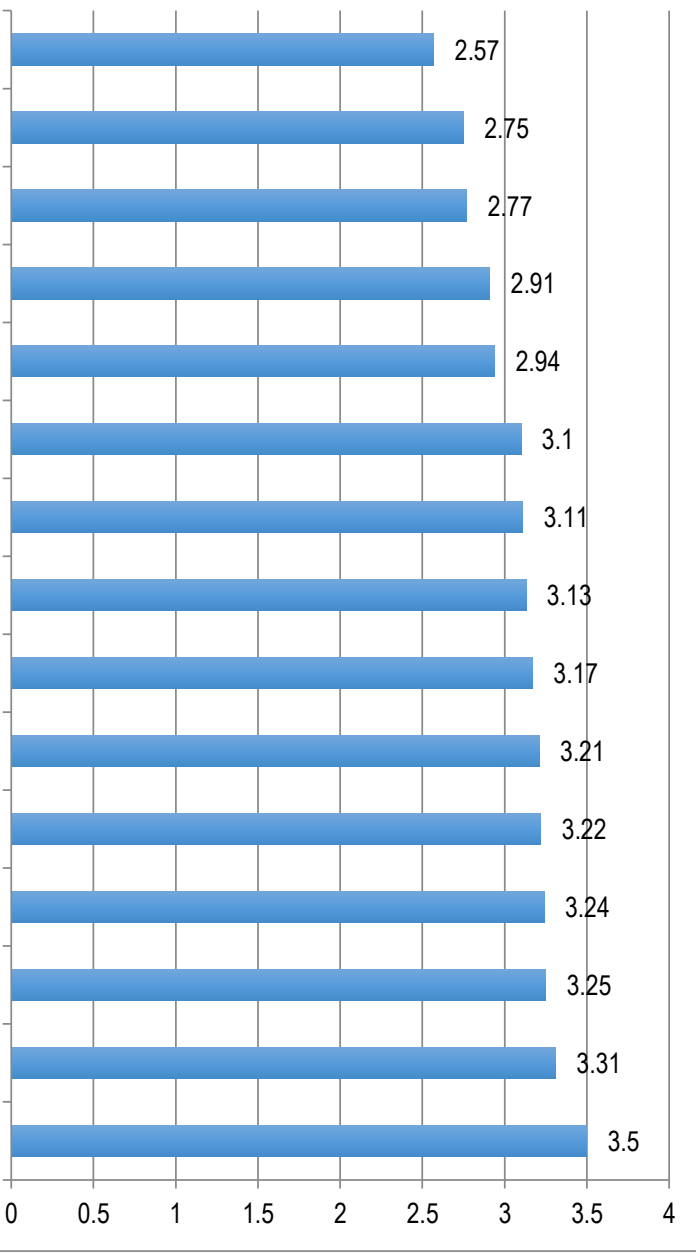

Source: ANECA 2005 
The highest-rated according to the Libro Blanco are "Ability and skill to express oneself with fluency and communicative effectiveness," "Ability to read and analyse specialised texts and documents," and "Ability and skill to collect, organise, analyse and process information and communication," while the lowest-rated is "Basic ability to communicate in other, neighbouring languages."

New facets and needs reflected in the profiles of interactive, multimedia journalists join the more traditional skills related to journalistic fundamentals, procedures in the creation of genres and formats, and the professional ethics the job requires.

The goal of this research is to rethink journalism studies in Spain. The study analyses whether the professional profiles and skills in journalism demanded by companies still correspond to those compiled in the Libro Blanco by ANECA (2005), or whether they have changed in the last decade because of the impact of the digital era and the rise of new labour requirements. Lastly, it determines whether we are creating journalists with criteria based on outdated profiles and skills.

\section{The Labour Market and New Journalistic Profiles}

Technological novelties and the ability to obtain information through mobile devices, software applications and social media networks have changed the skills necessary for working in news media. In the last decade, there has been a significant restructuring of the production of information, and this has had a direct impact on the professional profiles of journalists.

The following are some of the recently-established positions and fields: data delivery editor, social media editor (community manager), hypertext writer, web content manager, influencer, blogger, multimedia content editor, user-generated content editor, information architect, news moderator, usability expert, interactivity manager, web video editor, mobile journalism, journalism consulting, communication consulting and internet journalism research (Flores, 2013. p. 40).

The new media professions mentioned above involve skills and functions that overlap between them (Hayasaki, RocaCuberes and Singla, 2016). Companies themselves seem unable to distinguish the differences between some professions and others. The result is that, in recent years, many journalists have undertaken functions that have little or nothing to do with the education they received at university.

Pérez-Serrano, Rodríguez-Barba and Rodríguez-Pallares (2015), in their study "Mercado de la Comunicación y estudiantes de Periodismo. Estructura de la demanda de perfiles profesionales" ("The Communication Market and Journalism Students: Structure of the Demand for Professional Profiles"), also emphasise the lack of adaptation between company job offers and the new journalistic context. After analysing offers from the Centre for Job Orientation and Information (COIE) at the Universidad Complutense de Madrid in relation to students' internship contracts, they conclude that "the new occupations that entail digital communication activities, simply because they can be held by journalists, cannot properly be considered positions within the profession if they do not fulfill the social mission of information. As such, they are occupations or job opportunities for which a person with studies in journalism would be qualified, but which in no case should be admitted under the umbrella of the profession."

For their part, Gómez, Roses and García (2017) note the importance of recycling content within study plans that are in line with the reality of the labour market and which include knowledge that a priori is unrelated to a typical journalism background but is linked to current job offers for journalists. This knowledge includes computer skills, use of social networks and online marketing.

Recent reports from the sector indicate that, in years to come, companies will seek an increasing number of candidates with digital profiles (Inesdi, 2016; ADECCO, 2017; Magna Global). In 2015, the Libro Blanco para el Diseño de las Titulaciones Universitarias en el marco de la economía digital ("White Book for the Design of University Degrees within the Context of the Digital Economy") was created within the framework of the "Digital Agenda for Spain" and the "Education for Excellence" initiative through dialogue between industry, universities and administrations. It "supports the notion that university graduates should acquire skills that industry needs (...), [and] a revision of the trends of the digital economy sector, the profiles demanded by industry and the skills associated with these profiles" (Calvo-Sotelo, 2015).

The advent of social networks on the Internet has led companies to seek candidates with experience that will help them "manage their image" in these new platforms (Vinader, Abuín and Garcia, 2011, p. 78). These are professionals with a series of technological abilities and skills previously not considered. They are what, after analysing offers from Infojobs and 
conducting 10 interviews with leading innovation consultants and managers who have experience in Spain, the United States and Latin America, Palomo and Palau-Sampio (2016) referred to "adaptive journalists".

However, it seems professionals with these new skill sets are destined to encounter job insecurity. According to the 2017 Journalism Report by the Madrid Press Association (APM), "freelance journalists are more present in digital media sites (...) and $45 \%$ of freelance journalists earn less than 1000 euros per month" (APM, 2017).

\section{Objectives and Hypotheses}

Main Objective:

-Determine what profiles and professional skills in journalism are currently the most demanded by companies

Secondary Objectives:

-Determine whether professional skills in journalism, described in 2005 by the Libro Blanco Títulos de Grado en Comunicación (Bachelor's Degrees in Communication), correspond to the current demand of the labour market

-Analyse whether there is a connection between academic education and labour demand in the field of journalism

-Determine whether new professional journalism profiles related to the rise of new technologies and Web 2.0 are the most demanded

-Learn the types of employment contracts that are offered to media professionals

Hypotheses

$\mathrm{H} 0$ : There is a gap between university journalism studies in Spain and the labour market, so it is necessary to rethink these journalism studies so that the professional skills acquired coincide with those demanded by companies.

$\mathrm{H} 1$ : There is confusion among companies which make offers indiscriminately to graduates in disciplines which do not share the same study plans, especially offers related to the so-called new journalistic profiles.

\section{Methodology}

Quantitative analysis has been chosen: content analysis of the job offers to journalism graduates. Specifically, these were offers published in September 2017 on the two most-used job portals for job searches in Spain, Infojobs and Linkedln (Infoempleo-Adecco, 2016).

As Laurence Bardin notes, content analysis seeks to "obtain indicators (quantitative or otherwise) by systematic and objective procedures for describing the content of the messages, allowing the inference of knowledge relative to the social context of these messages" (1996: 32).

The justification for the period analysed is based on data from the Observatory for Occupations of the Spanish Public Employment Service, according to which the profession of journalist, in September 2017, shows a positive variation in hiring relative to the same month of the previous year $(9.50 \%)$ and $40 \%$ more hirings than in the previous month (SEPE, 2017).

After the first exploratory phase of searching for offers with Keywords like "community manager," "digital journalism," "journalism," "multimedia journalist," "copywriter" and "institutional relations," those which contained a bachelor's degree in journalism or, in the case of internships/grants, current studies in journalism as a minimum requisite were selected.

From an initial sample of 310 job offers, 156 were ultimately chosen, discarding those that were repeated or were not explicitly directed to journalism graduates. All the information provided in the job offers was organised into two categories based on the skills required and the descriptive information in the professional profiles demanded:

-Descriptions, with the goal of discovering the kind of contract stipulated in the job offers to media professionals. Included was information such as:

- Company name

- Sector

- Position 
- Province

- Type of contract

- Pay

-Skills, to analyse whether there is a connection between academic education and the professional skills and profiles required in the field of journalism. In this case, the information provided in the offers was organised as follows:

\section{Profiles sought:}

-Minimum studies required

-Minimum experience

-Field of employment

-Profiles sought

\section{Professional skills:}

-Job duties

-Knowledge of computer systems

-Knowledge of editing programs

-Knowledge of social networks

-Other knowledge

-Languages

It was necessary to analyse the adaptation of professional skills demanded by the labour market to those acquired in the university education of journalism graduates. To do this, we selected 10 of the 15 Libro Blanco (ANECA, 2005) skills that were largely reflected in the information provided in the job offers (job duties, knowledge of computer systems, knowledge of editing programs, knowledge of social networks, other knowledge and languages). These skills were grouped as follows:

\section{Table 1. Professional Skills}

\begin{tabular}{|c|c|}
\hline COMPANY REQUISITES & LIBRO BLANCO PROFESSIONAL SKILLS \\
\hline JOB DUTIES & $\begin{array}{l}\text { - } \quad \text { Ability and skill to express oneself with fluency and } \\
\text { communicative effectiveness } \\
\text { - } \quad \text { Ability to conceive, plan and carry out news or } \\
\text { - } \quad \text { Ability and skill to carry out basic journalistic tasks } \\
\text { - } \quad \text { Ability to experiment and innovate through the } \\
\text { knowledge and use of applied techniques and methods }\end{array}$ \\
\hline KNOWLEDGE OF COMPUTER SYSTEMS & Ability and skill to use computer systems and resources \\
\hline KNOWLEDGE OF EDITING & Ability and skill to design formal and aesthetic details \\
\hline KNOWLEDGE OF SOCIAL NETWORKS & $\begin{array}{l}\text { Ability and skill to communicate in the specific } \\
\text { language of all media } \\
\text { Ability and skill to use news and communication } \\
\text { technologies and techniques }\end{array}$ \\
\hline LANGUAGES & $\begin{array}{l}\text { - } \\
\text { English }\end{array}$ \\
\hline
\end{tabular}




\section{Source: prepared by the authors}

\section{Analysis of Results}

\subsection{Types of Job Offers for Journalists}

The largest number of job offers are concentrated in Spain's two biggest cities, Madrid and Barcelona. Three out of four $(77 \%)$ offers made through Linkedln and Infojobs correspond to Madrid (33\%) and Barcelona (44\%). Sevilla and Valencia follow far behind at $3 \%$ each.

As for the types of contracts offered, $31 \%$ do not specify what kind of contract is involved. Twenty-nine percent (29\%) are training contracts that involve grants or internships. Twenty percent $(20 \%)$ are fixed-length works and services contracts, $17 \%$ are indefinite contracts and $3 \%$ go to self-employed professionals. This indicates the instability of the hiring, which is 
also reflected in the fact that almost three out of every four $(68 \%)$ offers from the portals analysed do not include any information about the salary.

\section{Graph 2. Type of Contract for Journalists}

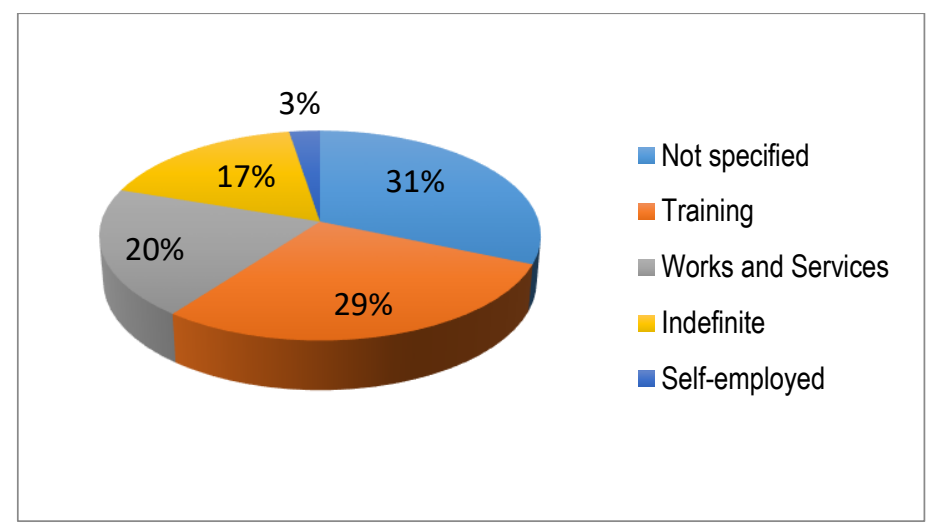

\section{Source: prepared by the authors}

The sectors of the companies which offer jobs or training to journalists or journalism students are quite diverse. The marketing and advertising sector offered the most jobs during the period analysed ( $26 \%)$, followed by Internet companies $(13 \%)$, many of which work in e-commerce. In the "Others" group (44\%) are companies which work in areas like the textile industry, pharmaceuticals, the chemical industry, the automobile industry and construction.

\section{Graph 3. Labour Sector of Companies that Seek Journalists}

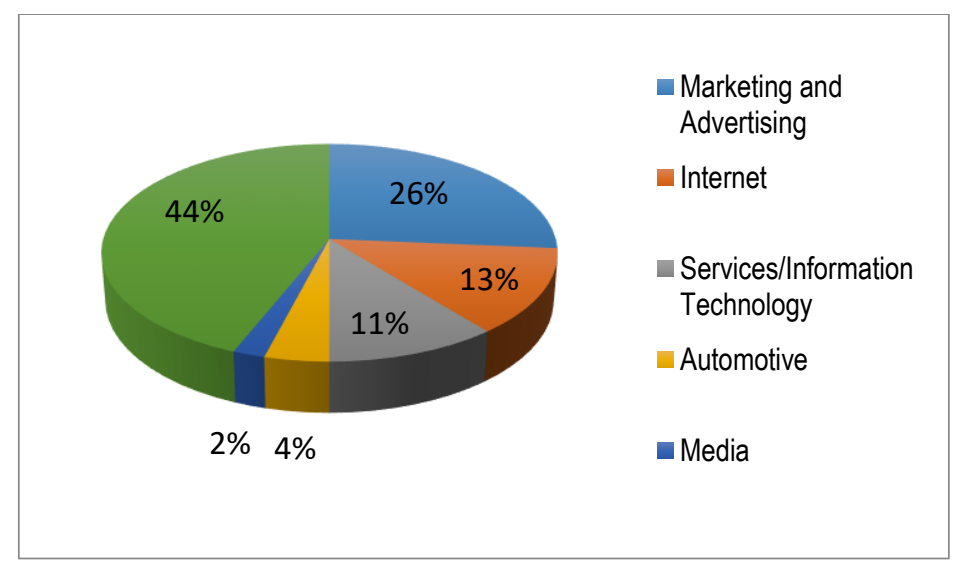

\section{Source: prepared by the authors}

Offers from the media sector represent only two percent $(2 \%)$ of the total.

\subsection{Professional Skills and Profiles Demanded}

\subsubsection{Professional Profiles}

This study is focused on offers to journalists. The minimum studies required in the job offers have been grouped into four categories. The offers that seek only journalism graduates or journalism students have been separated from offers that, in 
addition to journalism, include other degrees that include advertising, marketing, public relations, audiovisual communication, business administration, economics, and language and literature.

Only $31 \%$ of the offers are directed specifically to journalism graduates or students ( $26 \%$ and $5 \%$, respectively), while a large majority, $69 \%$, are directed to graduates $(57 \%)$ or students $(12 \%)$ in journalism or other degrees.

\section{Graph 4. Academic Education Required for Position}

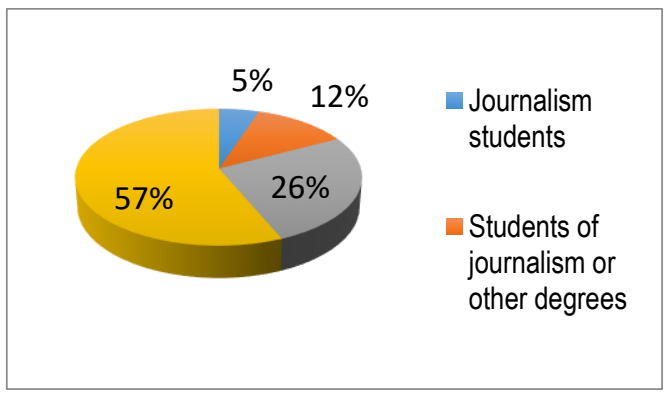

\section{Source: prepared by the authors}

In addition to minimum academic requirements, the companies highlight other transversal values like international experiences, having lived abroad, and in interest in the Internet and new technologies. They also look for "innovative, creative people," people "who know how to work in groups," people who are "proactive and can work under pressure" and, in one case, people "who can tolerate frustration".

On the basis of the Keywords that the companies publish and the area they note the candidates will work in, we find that almost half of the offers contain professional functions that would be performed in the area of marketing and advertising $(47 \%)$, followed by journalism and editing (28\%) and corporate communication $(25 \%)$.

\section{Graph 5. Field of Employment}

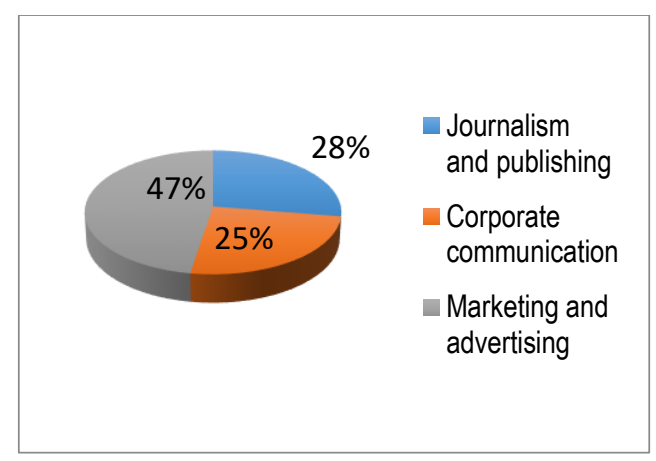

\section{Source: prepared by the authors}

This is a significant picture that indicates that the most demanded profiles are not among what we understand to be "journalism," but instead have more to do with marketing jobs.

In the job descriptions of the companies analysed, we see new profiles in the sector. Digital Content Manager (10\%), Community Manager (9\%), Communication Specialist (7\%) and Marketing Specialist (5\%) are some of the most used descriptors in English. Furthermore, we find positions called "journalist" (13\%), "copywriter" (9\%) or "account executive" $(5 \%)$, which are in line with a more traditional nomenclature. Included in the category "Others," which accounts for $14 \%$ of 
the offers, are more of these new profiles, such as "brand journalist," "content strategist," "SEO consultant" and "digital content manager."

\section{Graph 6. Old and New Positions Offered by Companies}

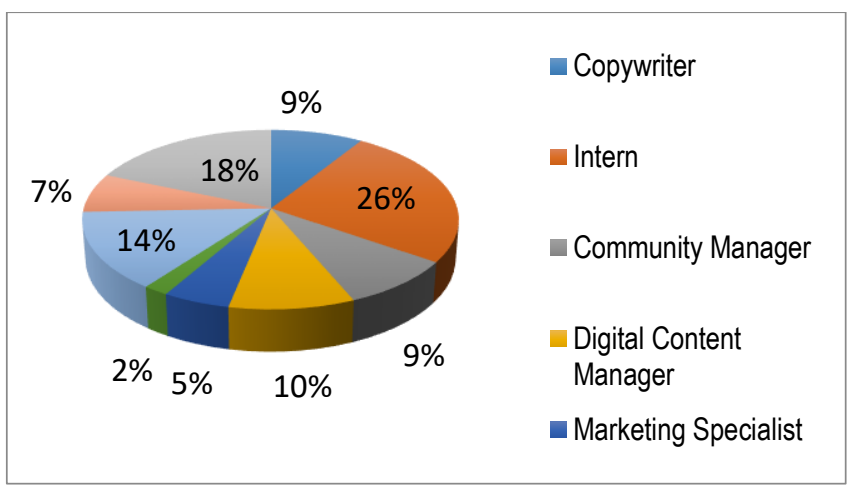

\section{Source: prepared by the authors}

The traditional positions (journalist and copywriter) account for $27 \%$ of the offers, while the new positions (community manager, digital content manager, marketing specialist, social media manager, communication specialist and "others") account for almost half (47\%), and $26 \%$ are for internships.

\subsubsection{Professional Skills Required by Companies}

The professional skills (know-how) compiled by ANECA and explicitly mentioned in the job duties of the 156 job offers analysed are the following:

- Ability to conceive, plan and carry out news or communication projects (58.33\%)

- Ability and skill to perform basic journalistic tasks (54.49\%)

- Ability and skill to express oneself with fluency and communicative effectiveness (30.77\%)

- Ability to experiment and innovate through the knowledge and use of applied techniques and methods $(21.79 \%)$

\section{Graph 7. Professional Skills and Job Duties}

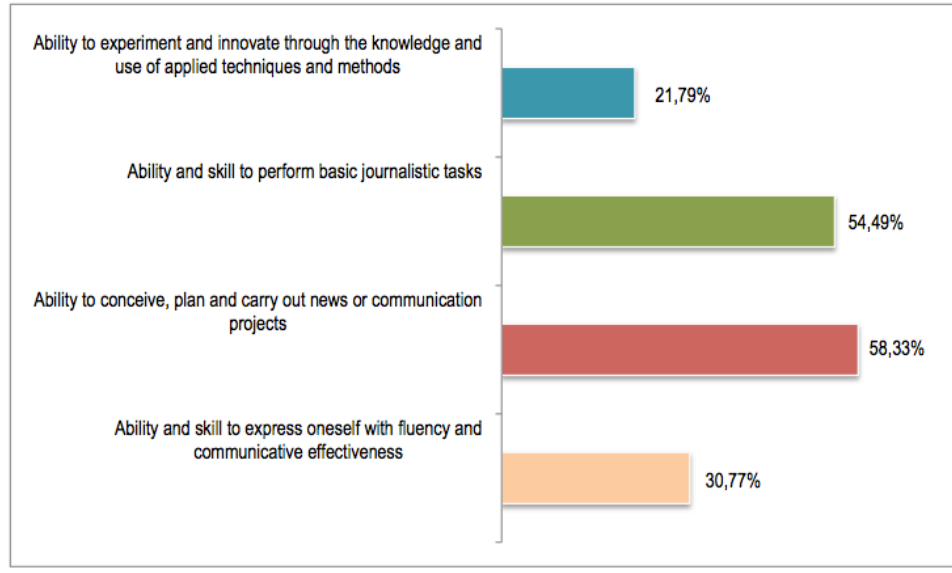




\section{Source: prepared by the authors}

Sixty-nine percent $(69 \%)$ of the offers analysed do not require knowledge of editing, while $31 \%$ of the companies specifically include different photography or video editing programs.

There appears to be a strong consensus on knowledge of social networks, as $72 \%$ of the companies require candidates to know Web 2.0 at the level of tools, platforms or SEO. The $28 \%$ of the offers that do not include knowledge of social networks correspond to more traditional positions like corporate communicators or account executives, or the offers directed to students.

\section{Graph 8. Specific Skills Required of Journalists}

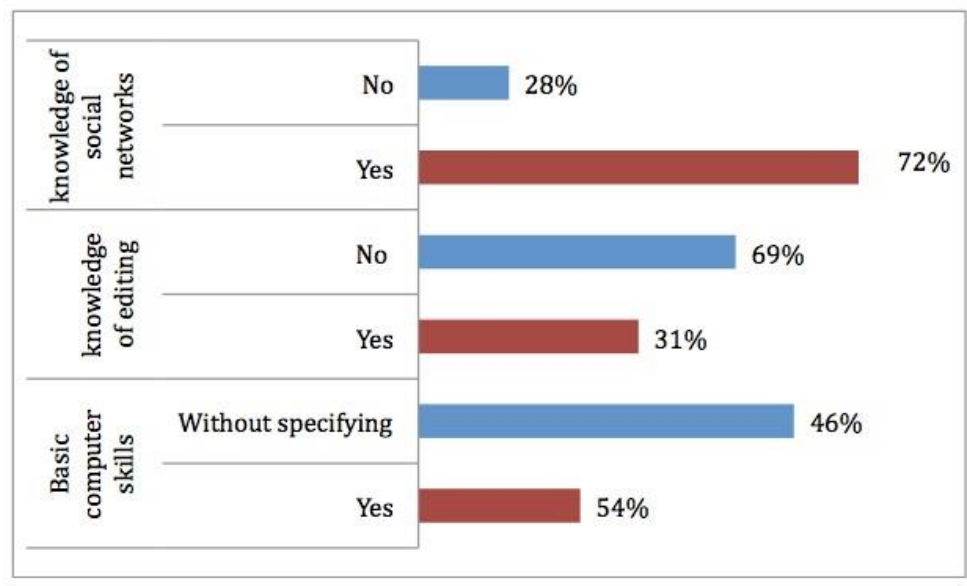

\section{Source: prepared by the authors}

The majority of the companies analysed, almost $80 \%$, value knowledge of another language apart from Spanish. Fifty-eight percent $(58 \%)$ of the offers demand a single language, which is usually English. Twenty-one percent $(21 \%)$ require knowledge of two languages.

Skills in using social networks and design and editing programs are the most valued by the companies, followed by knowledge of English. In addition, $21.79 \%$ of the companies requested creativity and innovation among the skills of the applicants.

The Libro Blanco includes five other professional skills more associated with traditional aspects of journalism. These skills, listed below, are not reflected in the job offers of the companies on Linkedln and Infojobs.

Ability to read and analyse specialised texts and documents

Ability and skill to collect, organise, analyse and process information and communication

Ability and skill to search for, select and prioritise any type of source or document

Ability and skill to present reasoned ideas

Understanding of the data and mathematical operations performed and currently used in the media

Five of the 15 professional skills in the Libro Blanco, then--one third--are not reflected in the current demands of the labour market.

\section{Conclusions}

On the basis of the results obtained, we can affirm that the initial hypothesis of this research has been validated. There is a gap between journalism studies in Spain and the labour market demand. The professional skills that are required of 
journalists in the labour market today differ from the professional skills in journalism studies described by the Spanish National Agency for Quality Assessment and Accreditation (ANECA) in 2005.

Some conclusions coincide with those in other research (Palomo and Palau-Sampio, 2016). However, one sees that, in our research from 2017, knowledge and use of social networks was already the most valued requisite, having appeared in $72 \%$ of the offers. As such, it seems that digital journalists are the most sought-after by companies.

Nonetheless, the new professional setting of journalism does not seem to be clearly manifested in the offers of companies, as Pérez-Serrano, Rodríguez-Barba and Rodríguez-Pallares already noted (2015). It is not clearly reflected in this study, either. Knowledge of marketing is included in many (47\%) of the positions offered on Linkedln and Infojobs to journalists, when this is not a subject considered in the study plans of journalism. This leads us to validate our second hypothesis, which stated that companies do not clearly know what skills a journalism graduate should have.

It is also important to note that journalism with regard to its traditional aspects, journalism in the purely informative sense, is not reflected in the requirements of the company offers.

After the thorough analysis of the data, we can conclude that there is a large gap between the academic education that students in Spanish journalism departments currently receive and what companies apparently require today to fill mediarelated positions. In light of this conclusion, there must be greater concordance between the business world and universities.

It is also important that the content and subjects of study plans be revised so that future journalists have a place in the labour market, which is becoming more interdisciplinary in nature. This revision should not forget the importance of the traditional skills of journalism, which companies seem largely to overlook.

Research carried out in the Research Group for Communication and Digital Information, recognised by the government of Aragón and financed by the European Regional Development Fund within the project "Determinants of the Evolution of Journalistic Fundamentals and Skills in Practice, According to the Type and Ownership of News Company," CONDEVOLPER (UZ-2017-HUM-04).

\section{References}

[1] ANECA (2005). Libro Blanco de los Títulos de Grado en Comunicación. Agencia Nacional de Evaluación de la Calidad y Acreditación. Recuperado de http://www.aneca.es/activin/docs/libroblanco_comunicacion_def.pdf

[2] APM (2017). El 45\% de los periodistas autónomos cobra menos de 1.000 euros al mes, porcentaje diez puntos superior al de 2016. Recuperado de: https://www.apmadrid.es/comunicado/el-45-de-los-periodistas-autonomos-cobra-menos-de-1-000euros-al-mes-cifra-diez-puntos-superior-que-en-2016/

[3] Bardin, L. (1996). Análisis de contenido. Madrid: Akal.

[4] Beneyto, A. (1958). España. En Unesco (ed.) La formación de periodistas. Estudio mundial sobre la preparación del personal de la información (pp. 199-202). Paris: Unesco. Recuperado de http://unesdoc.unesco.org/images/0013/001353/135346so.pdf

[5] Benito, A. (1967). Evolución de los estudios de Periodismo en el mundo. Cuadernos de Trabajo 11, 13-36.

[6] Calvo-Sotelo, V. (2015). Prólogo. En Libro Blanco para el Diseño de las Titulaciones Universitarias en el marco de la economía digital. Ministerio de Industria, Energía y Turismo. Recuperado de: 
http://www.agendadigital.gob.es/Paginas/404.aspx?requestUrl=http://www.agendadigital.gob.es/planesactuaciones/Bibliotecacontenidos/3.\%20Formación\%20de\%20excelencia/Libro-Blanco.pdf

[7] Flores, J. (2013). Perfiles emergentes en la industria de la Comunicación on-line. En M.C., Agustín Lacruz, C. Marta-Lazo y I. Ubieto Artur, (coord.) (2013). Perfiles profesionales y espacios de empleo en Información y Comunicación (pp. 31-51). Madrid: Icono 14.

[8] Galdón, G. (1999). La enseñanza del Periodismo. Una propuesta de futuro. Barcelona: CIMS.

[9] Gómez-Calderón, B., Roses, S. y García-Borrego, M. (2017). Los nuevos perfiles profesionales del periodista desde la perspectiva académica española. Revista Mediterránea de Comunicación/Mediterranean Journal of Communication 8 (1), 191-200. Recuperado de https://www.doi.org/10.14198/MEDCOM2017.8.1.14

[10] Gordon, M. (1991). La enseñanza del periodismo en el mundo occidental. Estudio histórico y comparado de tres escuelas. Madrid: Universidad Complutense.

[11] Graña, M. (1927). Escuelas de Periodismo. Conferencia pronunciada en la Sociedad de Estudios Vasca. Enseñanza profesional, 240-252. Recuperado de http://www.euskomedia.org/PDFAnlt/congresos/04/04240252.pdf

[12] Hayasaki, P., Roca-Cuberes, C. y Singla, C. (2016). New Professional Profiles and Skills in the Journalistic Field: A Scoping Review and In-Depth Interviews with Professionals in Spain. Brazilian Journalism Research 12, 14-33.

[13] Humanes, M. L. (1997). La formación de los periodistas en España. Tesis doctoral. Universidad Complutense de Madrid.

[14] INESDI (2016). Top 25. Profesiones digitales 2016. España. Recuperado de https://www.inesdi.com/descargas/Top25Profesiones-Digitales-2016.pdf

[15] Infoempleo-Adecco (2016). Redes sociales y mercado de trabajo. Madrid. Recuperado de http://www.adeccorientaempleo.com/webwp/wp-content/uploads/2017/02/Informe-2017-Empleo-y-Redes-InfoempleoAdecco2.pdf

[16] Infojobs \& ESADE. (2016). Estado del mercado laboral en España. Recuperado de https://nosotros.infojobs.net/prensa/informes/informe-el-estado-del-mercado-laboral-espanol-2016

[17] Magna Global (2017). Magna Advertising Forecasts Spring Update. Recuperado de https://www.magnaglobal.com/wpcontent/uploads/2017/06/MAGNA-Global-Ad-Forecast-Spring-Update-June-2017-PRExecutive-Summary.pdf

[18] Marta-Lazo, C. (2010) (Coord.). El proceso de reconversión de la comunicación en el EEES. Icono 14 14, 1-7. Recuperado de http://www.icono14.net/index.php/presentacion/el-proceso-de-reconversion-de-la-comunicacion-en-el-eee

[19] Marta-Lazo, C. y Vadillo Bengoa, N. (coord.) (2013). Evaluación de la implantación del EEES en los estudios de comunicación. Tenerife: Cuadernos Artesanos de Latina.

[20] Marta-Lazo, C., Agustín Lacruz, M.C. y Ubieto, I. (coord.) (2012). Competencias interdisciplinares para la comunicación y la información en la sociedad digital. Madrid: Icono 14

[21] Palomo, B. y Palau-Sampio, D. (2016). El periodista adaptativo. Consultores y directores de innovación analizan las cualidades del profesional de la comunicación. El profesional de la información 25 (2), 88-195.

[22] Pérez Serrano, M.J., Rodríguez Barba, D. y Rodríguez Pallarés, M. (2015). Mercado de la Comunicación y estudiantes de Periodismo. Estructura de la demanda de perfiles profesionales. Revista Latina de Comunicación Social 70, 209-229.

[23] Real, E. (2012). Los estudios de Periodismo en España, competencias y destrezas. En C. Marta-Lazo, M-C. Agustín Lacruz y Ubieto Artur, I. (coord.). Competencias interdisciplinares para la comunicación y la información en la sociedad digital (pp. 115-144). Madrid: Icono 14.

[24] Rodrigo-Alsina, M. y Lazcano, D. (2014). La enseñanza en Comunicación y su proceso de adaptación al EEES como objeto de estudio: una visión panorámica. Comunicación y Sociedad 27(2), 221-239.

[25] Sánchez-García, P. (2016). Los efectos de la primera fase del EEES en la enseñanza del periodismo en España: mayor especialización y formación práctica. Communication \& Society 29 (1), 125-143.

[26] Sierra, J. y Cabezuelo, F. (Coords.) (2010). Competencias y perfiles profesionales en los estudios de Ciencias de la Comunicación. Madrid: Fragua.

[27] Vinader Segura, R., Abuín Vences, N. y García García, A. (2011). El impacto de la web 2.0 en los nuevos perfiles audiovisuales. TELOS. Cuadernos de Comunicación e Innovación 87, 74-87.

[28] Vivar, H., Abuín, N., García, A., Vinader, R. y Núñez, P. (2010). La transición al EEES: la especificidad como vía para incrementar la tasa de inserción laboral de los titulados en Comunicación. En J. Sierra, y F. Cabezuelo, (Coords.). Competencias y perfiles profesionales en los estudios de Ciencias de la Comunicación (pp. 27-43).Madrid: Fragua. 